\title{
日本鳥学会会長就任にあたってのご挨拶 Inaugural address of the new president
}

日本鳥学会は 1912 年に設立され，今年で 106 年目を迎える長い歴史のある学会です。その会長を 西海 功前会長から引き継ぐことになり, 大変名誉なことであると同時に, これまでの良き伝統を継承 し, さらに発展させるべき責任の重さを痛感しています。幸いなことに, 最近の日本鳥学会は会員約 1,200 名となり, その発展は著しいものがあります。学会の顔ともいえる学会誌は, 2002 年から英文誌 (Ornithological Science) と和文誌（日本鳥学会誌）に分離し，いずれも定期的に順調に刊行されており， 内容も年々充実しています．もう一つの重要な出版物である日本鳥類目録の第 7 版（2012 年）は 6 版か ら 12 年で改訂され, 第 5 版から第 6 版に 26 年も要した遅れを取り戻しました。今後も 10 年毎の改訂を めざして，鳥類分類委員会や日本産鳥類記録委員会が準備を進めています．創立 100 周年のシンポジウム （2012 年）や，国際鳥類学会議（2014 年）の日本での初開催も記憶に新しいところです.

鳥学会の主要な行事である年次大会の参加者も年々増加の傾向にあり, 筑波大学で開催された 2017 年 度は, 参加者 568 名の大盛況でした。私は学生時代から鳥学会にお世話になっていますので, 45 年前位 になるかと思いますが, そのころの大会は参加者が 40-50名でしたので, 隔世の感があります. 以来可能 な限り大会に参加するとともに，鳥類保護委員会や評議員会にも参画させていただきました，そのおかげ で，多くのかたと知り合うことができ，鳥の研究の上でたくさんの情報と刺激を得ることができました． 近年のように情報がたやすく大量に入手できる時代になっても, やはり直接生の人間を通じて研究発表を 聞き, 話し合える鳥学会の大会に参加することは, 大切な機会であり, 研究生活の財産になるものです. したがって今後の鳥学会のさらなる発展には, 大会の充実が大きな課題であると思います.

しかしながら，現実問題としては，大会の開催には色々な困難があります。まず会場の確保，大会を受 け入れてくれる研究者や機関の同意, 会場費などの費用負担の増加, 等々. そのため, 学会として大会準 備金を予算化し，大会実行委員会の準備が円滑にできることなどを盛り込んだ日本鳥学会大会規定（2016 年 9 月 18 日）が制定されましたが，さらにより魅力的な大会にしていく工夫を進めていく所存です.

日本鳥学会の特色のひとつは, 鳥を軸にして, 大学・研究機関・NPO などに属する研究者, 調査会社 の職員, アマチュアの研究者やバードウォッチャー, 大学生, そして高校生や中学・小学生まで, 鳥に興 味を持つ多彩な人たちが関わっていること.さらに鳥を科学する様々な学問分野からの参加があることで す。こうしたメンバーの日本鳥学会との関わりや期待することは多岐にわたるものと思われます。それを 満たすには, 上に述べた学会誌への投稿や購読, 大会やシンポジウム, 各種委員会への参加の他に, 日常 的で身近なものとして, ホームページや鳥学通信をより活用する可能性を, 広報委員会とともに探ってい きたいと考えています.

一方で, 絶滅危惧種の増加, 風力発電や太陽光発電施設による鳥類への悪影響, また鳥インフルエンザ などの感染症問題も重大な課題です。これら鳥－環境－人間の問題に日本鳥学会としてどのように対処し 貢献できるかについて，鳥類保護委員会を中心に議論をし，可能なことから取り組んでいこうと思います．

これから 2 年間, 事務局一同は, 評議員会, 各種委員会との連携を深めて, 日本鳥学会の運営と活動が 円滑に進むよう努力する所存です。 どうか会員の皆さんには,「鳥」への知識と関心を深め, 調查研究を 進めるとともに，鳥学と日本鳥学会の発展に積極的に参加・協力いただけますよう, よろしくお願いいた します。

2018 年 1 月

日本鳥学会会長

President, the Ornithological Society of Japan

尾崎清明

Dr. Kiyoaki OZAKI 